\title{
PENGARUH KETAATAN ATURAN AKUNTANSI DAN PERILAKU TIDAK ETIS TERHADAP KECENDERUNGAN KECURANGAN AKUNTANSI DENGAN PENGENDALIAN INTERNAL SEBAGAI VARIABEL PEMODERASI (Studi Pada Perusahaan-Perusahaan Swasta Di Provinsi Jawa Tengah)
}

\author{
Eko Darmawan \\ Program Studi Akuntansi \\ STIE Putra Bangsa Kebumen \\ suwandi.darmawan@yahoo.co.id
}

\begin{abstract}
ABSTRAK
Kasus kecenderungan kecurangan akuntansi di Indonesia terjadi secara berulangulang. Media massa banyak memberitakan hal tersebut sehingga bagi masyarakat kasus kecenderungan kecurangan akuntansi sepertinya bukan rahasia lagi. Pada sektor publik kecenderungan kecurangan akuntansi dilakukan dalam bentuk kebocoran anggaran pendapatan dan belanja negara. Di sektor swasta bentuk kecenderungan kecurangan akuntansi juga terjadi dalam bentuk yang sama yaitu ketidaktepatan dalam membelanjakan sumber dana. Penelitian ini bertujuan untuk menganalisis pengaruh ketaatan aturan akuntansi dan perilaku tidak etis terhadap kecenderungan kecurangan akuntansi dengan pengendalian internal sebagai variabel pemoderasi.

Metode penelitian yang digunakan dalam penelitian ini adalah explanatory research, yang akan menjelaskan hubungan kausal antara variabel independen tersebut terhadap variabel dependen melalui pengujian hipotesis Dalam penelitian ini, peneliti mengumpulkan data primer dengan cara kuesioner. Kuesioner diberikan kepada Kepala Bagian Akuntansi dan Staff Keuangan Perusahaan-Perusahaan Swasta di Provinsi Jawa Tengah yang dijadikan sampel penelitian atau responden penelitian. Sedangkan analisis data yang digunakan antara lain uji asumsi klasik dan analisis regressi linear berganda.

Berdasarkan hasil penelitian diketahui bahwa (1) Ketaatan aturan akuntansi berpengaruh positif dan signifikan terhadap kecenderungan kecurangan akuntansi. Artinya semakin taat Perusahaan-Perusahaan Swasta Di Provinsi Jawa Tengah dalam menerapkan aturan akuntansi akan menyebabkan kecurangan akuntansi semakin menurun; (2) Perilaku tidak etis berpengaruh positif dan signifikan terhadap kecenderungan kecurangan akuntansi. Artinya semakin meningkat perilaku tidak etis dalam perusahaan akan menyebabkan kecurangan akuntansi semakin meningkat; (3) Pengendalian internal berpengaruh positif dan signifikan terhadap kecenderungan kecurangan akuntansi. Artinya semakin efektif pengendalian internal dalam perusahaan akan menyebabkan kecurangan akuntansi semakin menurun; (4) Pengendalian internal secara positif dan sinifikan dapat memperkuat ketaatan aturan akuntansi dan pengaruhnya terhadap kecenderungan kecurangan akuntansi. Artinya semakin efektif pengendalian internal menyebabkan ketaatan akuntansi dalm perusahan semkain meningkat dan mendorong kecurangan akuntansi semakin menurun; (5) Pengendalian internal secara positif dan sinifikan dapat memperkuat perilaku tidak etis dan pengaruhnya terhadap kecenderungan kecurangan akuntansi. Artinya semakin efektif pengendalian internal menyebabkan perilaku tidak etis dalam perusahaan semakin menurun dan mendorong kecurangan akuntansi semakin menurun.
\end{abstract}

\section{Kata Kunci: Ketaatan Aturan Akuntansi, Perilaku Tidak Etis, Kecenderungan Kecurangan Akuntansi, Pengendalian Internal}




\section{PENDAHULUAN}

Kecurangan akuntansi telah berkembang di berbagai negara, termasuk di Indonesia. Di USA kecurangan akuntansi telah berkembang secara luas (Sobel, 1977). Spathis (2002) menjelaskan bahwa di USA kecurangan akuntansi menimbulkan kerugian yang sangat besar di hampir seluruh industri. Kerugian dari kecurangan akuntansi di pasar modal adalah menurunnya akuntabilitas manajemen (Pritchard, 1999) membuat para pemegang saham meningkatkan biaya monitoring terhadap manajemen.

Kasus kecenderungan kecurangan akuntansi di Indonesia terjadi secara berulang-ulang. Media massa banyak memberitakan hal tersebut sehingga bagi masyarakat kasus kecenderungan kecurangan akuntansi sepertinya bukan rahasia lagi. Pada sektor publik kecenderungan kecurangan akuntansi dilakukan dalam bentuk kebocoran anggaran pendapatan dan belanja negara. Di sektor swasta bentuk kecenderungan kecurangan akuntansi juga terjadi dalam bentuk yang sama yaitu ketidaktepatan dalam membelanjakan sumber dana. Hal demikian terjadi pula pada Badan Usaha Milik Negara (Wilopo, 2006).

Kecurangan akuntansi juga telah mendapat banyak perhatian publik sebagai dinamika yang menjadi pusat perhatian para pelaku bisnis di dunia. Bahkan di Indonesia, kecurangan akuntansi sudah menjadi kebiasan dari tahun ke tahun. Himbauan tersebut diungkapkan oleh Cohen dkk (2011) dan Abdullatif (2013) yang menyatakan bahwa kecurangan dalam perusahaan disebabkan oleh perilaku tidak etis dari manager dan ketidaktaatan pada standar peraturan yang ada.

Perilaku tidak etis juga mempengaruhi banyaknya penyimpanganpenyimpangan yang terjadi di Indonesia. Perilaku tidak etis yaitu perilaku menyimpang yang dilakukan seseorang untuk mencapai suatu tujuan tertentu. Perilaku tidak etis berbeda dengan kecurangan akuntansi. Pada kecurangan akuntansi lebih menekankan pada adanya kesengajaan untuk melakukan tindakan penghilangan atau penambahan jumlah tertentu, sehingga terjadi salah saji dalam laporan keuangan untuk tujuan tertentu (Laughin, 2009; Rawasdeh, 2013). Sedangkan perilaku tidak etis merupakan perilaku seseorang yang menyalahgunakan kekuasaan maupun jabatan untuk tujuan tertentu. Namun demikian, baik perilaku tidak etis maupun kecenderungan kecurangan akuntansi memiliki peranan dalam banyaknya korupsi di Indonesia.

Tingginya kecenderungan kecurangan akuntansi yang dilakukan oleh karyawan disebabkan oleh informasi yang diterima manajemen tidak akurat, tidak relevan, tidak lengkap dan tidak tepat waktu sehingga menjadi penghambat bagi para pembuat keputusan dalam mengambil kebijakan yang tepat bagi pencapaian tujuan perusahaan. Oleh karena itu, diperlukan adanya pengendalian internal untuk mengarahkan, mengawasi, pelaporan akuntansi. Pengendalian internal ini berperan penting untuk mencegah dan mendeteksi kecurangan serta melindungi sumber daya organisasi, baik yang berwujud maupun tidak.

Wilopo (2006) membuktikan bahwa kecenderungan kecurangan akuntansi dan perilaku tidak etis manajemen dapat diturunkan dengan meningkatkan ketaatan aturan akuntansi, kefektifan pengendalian internal, moralitas manajemen, serta menghilangkan asimetri informasi. Ketaatan pada aturan akuntansi merupakan tindakan atau perbuatan yang harus dijalankan berpedoman pada aturan yang dalam hal ini adalah aturan akuntansi (Adelin dan Fauzihardani, 2013:263). Aturan akuntansi dibuat sedemikian rupa sebagai dasar dalam penyusunan laporan keuangan. Dalam standar akuntansi terdapat aturan-aturan yang harus ditaati dalam pegukuran dan penyajian laporan keuangan yang berpedoman terhadap aturan-aturan yang dikeluarkan oleh Ikatan Akuntansi 
Indonesia (IAI). Informasi yang tersedia dilaporan keuangan sangat dibutuhkan bagi investor dan manajemen jadi harus dapat diandalkan. Dengan demikian ketaatan pada aturan akuntansi diperlukan untuk menjaga keandalan informasi tersebut dan menghindari tindakan yang dapat merugikan perusahaan atau organisasi.

Dengan pertimbangan tersebut dan semakin banyaknya kasus kecurangan akuntansi yang melibatkan perusahaan, maka penting dilakukan penelitian kecurangan akuntasi untuk mengetahui faktor apa yang mempengaruhi perusahaan melakukan kecurangan akuntansi. Meski kecurangan akuntansi ini diduga sudah menahun, namun di Indonesia belum terdapat kajian teoritis dan empiris secara komprehensif. Oleh karena itu fenomena ini tidak cukup hanya dikaji oleh ilmu akuntansi, tetapi perlu melibatkan disiplin ilmu yang lain.

Berdasarkan permasalahan yang telah diuraikan, maka peneliti tertarik untuk meneliti lebih lanjut berkaitan dengan "Pengaruh Ketaatan Aturan Akuntansi dan Perilaku Tidak Etis terhadap Kecenderungan Kecurangan Akuntansi dengan Pengendalian Internal Sebagai Variabel Pemoderasi (Studi Pada Perusahaan-Perusahaan Swasta Di Provinsi Jawa Tengah)".

\section{Rumusan Masalah}

Berdasarkan latar belakang yang telah diuraikan di atas, maka permasalahan yang akan dibahas dalam penelitian dirumuskan dalam bentuk pertanyaan penelitian sebagai berikut :

1) Apakah semakin taat perusahaan dalam menerapkan aturan akuntansi akan menyebabkan kecurangan akuntansi semakin menurun?

2) Apakah semakin meningkat perilaku tidak etis dalam perusahaan akan menyebabkan kecurangan akuntansi semakin meningkat?

3) Apakah semakin efektif pengendalian internal dalam perusahaan akan menyebabkan kecurangan akutansi semakin menurun?

4) Apakah efektivitas pengendalian internal menyebabkan ketaatan akuntansi dalam perusahaan semakin meningkat dan mendorong kecurangan akuntansi semakin menurun?

5) Apakah efektivitas pengendalian internal meyebabkan perilaku tidak etis dalam perusahaan semakin menurun dan mendorong kecurangan akuntansi semkain menurun?

\section{KERANGKA TEORITIS DAN} PENGEMBANGAN HIPOTESIS

\subsection{Kerangka Teoritis}

\subsubsection{Kecurangan Akuntansi}

IAI (2001: 38) menjelaskan kecurangan akuntansi sebagai:

1) Salah saji yang timbul dari kecurangan dalam pelaporan keuangan yaitu salah saji atau penghilangan secara sengaja jumlah atau pengungkapan dalam laporan keuangan untuk mengelabuhi pemakai laporan keuangan.

2) Salah saji yang timbul dari perlakuan tidak semestinya terhadap aktiva (seringkali disebut dengan penyalahgunaan atau penggelapan) berkaitan dengan pencurian aktiva entitas yang berakibat laporan keuangan tidak disajikan sesuai dengan prinsip akuntansi yang berlaku umum di Indonesia. Perlakuan tidak semestinya terhadap aktiva entitas dapat dilakukan dengan berbagai cara, termasuk penggelapan tanda terima barang/uang, pencurian aktiva, atau tindakan yang menyebabkan entitas membayar barang atau jasa yang tidak diterima oleh entitas. Perlakuan tidak semestinya terhadap aktiva dapat disertai dengan catatan atau dokumen palsu atau yang menyesatkan dan dapat menyangkut satu atau lebih individu di antara manajemen, karyawan, atau pihak ketiga.

Dari perspektif kriminal, kecurangan akuntansi dikategorikan sebagai kejahatan kerah putih (white-collar crime). 
Sutherland, sebagaimana dikutip oleh Geis dan Meier (2007:75), dalam Wilopo (2006: 32), menjelaskan bahwa kejahatan kerah putih dalam dunia usaha diantaranya berbentuk salah saji atas laporan keuangan, manipulasi di pasar modal, penyuapan komersial, penyuapan dan penerimaan suap oleh pejabat publik secara langsung atau tidak langsung, kecurangan atas pajak, serta kebangkrutan. Dari definisi-definisi di atas, tampak perbedaan pengertian dari kecurangan akuntansi. IAI tidak secara eksplisit menyatakan bahwa kecurangan akuntansi merupakan kejahatan. Sebaliknya Sutherland (2010:66) sebagai pakar hukum menganggap kecurangan akuntansi sebagai kejahatan.

\subsubsection{Perilaku Tidak Etis}

Wilopo (2006:44) menjelaskan bahwa perilaku tidak etis merupakan sesuatu yang sulit untuk dimengerti, yang jawabannya tergantung pada interaksi yang kompleks antara situasi serta karakteristik pribadi pelakunya. Meski sulit dalam konteks akuntansi, dan hubungannya dengan pasar sering tidak jelas, namun memodelkan perilaku perlu dipertimbangkan guna memperbaiki kualitas keputusan serta mengurangi biaya yang berkaitan dengan informasi dan untuk memperbaiki tersedianya informasi yang tersedia bagi pasar (Hendriksen, 2002:237).

Perusahaan sebagai pribadi artifisial memiliki tanggung jawab moral dan sosial, yang pada tingkat operasional diwakili secara formal oleh manajemen (Keraf, 2008: 113-136). Dengan mengacu pada dimensi perilaku yang menyimpang dalam bekerja dari Robinson (2005: 113), Tang et al., (2003: 106) menjelaskan indikator dari perilaku yang menyimpang atau tidak etis dalam perusahaan. Perilaku ini terdiri dari perilaku yang menyalahgunakan kedudukan/posisi (abuse position), perilaku yang menyalahgunakan kekuasaan (abuse power), perilaku yang menyalahgunakan sumber daya organisasi (abuse resources), serta perilaku yang tidak berbuat apa-apa (no action). Penelitian ini meminjam konsep Tang et al., (2003: 112) untuk menjelaskan indikator perilaku tidak etis perusahaan.

\subsubsection{Keefektifan Pengendalian Internal}

Pengendalian merupakan suatu tindakan atau aktivitas yang dilakukan manajemen untuk memastikan (secara memadai, bukan mutlak) tercapainya tujuan dan sasaran organisasi. Tindakan/aktivitas pengendalian yang ada dalam organisasi dikelompokkan dalam (BPK, 2009 dalam Prasetyo, 2011: 37) :

1) Pengendalian Pencegahan (preventive controls) bertujuan untuk mencegah galat (errors) atau peristiwa yang tidak diinginkan terjadi.

2) Pengendalian Pendeteksian (detective controls) bertujuan untuk menginformasikan kepada manajemen galat atau masalah yang sedang terjadi atau beberapa saat setelah terjadi.

3) Pengendalian Pemulihan (corrective controls) biasanya digunakan bersama dengan pendeteksian, bertujuan untuk memperbaiki kembali dari akibat terjadinya peristiwa yang tidak diinginkan.

Menurut COSO, pengendalian internal merupakan suatu proses yang dipengaruhi oleh direksi organisasi, manajemen, dan personel lainnya, yang didesain untuk memberikan keyakinan memadai akan tercapainya tujuan dalam kategori berikut (BPK, 2009 dalam Prasetyo, 2011:39) :

1) Efektivitas dan efisiensi operasi

2) Keandalan pelaporan keuangan

3) Ketaatan pada hukum dan peraturan yang berlaku

Menurut Prasetyo (2011: 52) tujuan pengendalian internal adalah menjamin manajemen perusahaan agar :

1) Tujuan perusahaan yang ditetapkan akan dapat dicapai.

2) Laporan keuangan yang dihasilkan perusahaan dapat dipercaya.

3) Kegiatan perusahaan sejalan dengan hukum dan peraturan yang berlaku. 


\subsubsection{Ketaatan Aturan Akuntansi}

Dalam suatu organisasi atau perusahaan terdapat aturan yang menjadi dasar perilaku manajemen yang dibuat untuk mencegah terjadinya aktivitas menyimpang yang dapat merugikan perusahaan. Salah satu aturan dalam suatu perusahaan atau organisasi adalah aturan akutansi. Aturan akuntansi mengatur tentang pelaporan keuangan yang berpedoman pada PSAK yang dikeluarkan oleh IAI. Informasi yang tersedia dalam laporan keuangan sangat penting bagi investor dan manajemen sehingga harus dapat diandalkan. Sehingga dibutuhkan suatu aturan untuk menjaga keandalan informasi tersebut dan menghindari tindakan yang menyimpang yang dapat merugikan perusahaan atau organisasi.

\subsection{Hipotesis Penelitian}

1. Semakin taat perusahaan dalam menerapkan aturan akuntansi akan menyebabkan kecurangan akuntansi semakin menurun.

2. Semakin meningkat perilaku tidak etis dalam perusahaan akan menyebabkan kecurangan akuntansi semakin meningkat.

3. Semakin efektif pengendalian internal dalam perusahaan akan menyebabkan kecurangan akuntansi semakin menurun.

4. Efektivitas pengendalian internal menyebabkan ketaatan akuntansi dalm perusahan semkain meningkat dan mendorong kecurangan akuntansi semakin menurun.

5. Efektivitas pengendalian internal menyebabkan perilaku tidak etis dalam perusahaan semakin menurun dan mendorong kecurangan akuntansi semakin menurun.

\section{METODE PENELITIAN}

\subsection{Rancangan Penelitian}

Pada rancangan sebuah penelitian akan dijelaskan mengenai langkah awal hingga akhir mengenai tata cara dilakukanya penelitian ini membentuk proses dan hasil yang objektif, efektif, valid, dan efisien. Secara umum tujuan penelitian ini adalah untuk membuktikan dan menganalisis pengaruh ketaatan aturan akuntansi dan perilaku tidak etis terhadap kecenderungan kecurangan akuntansi dengan pengendalian internal sebagai variabel pemoderasi. Berdasarkan tujuan penelitian tersebut, maka penelitian ini termasuk jenis penelitian penjelasan atau explanatory research, yang akan menjelaskan hubungan kausal antara variabel independen tersebut terhadap variabel dependen melalui pengujian hipotesis (Sugiyono, 2012).

\subsection{Metode Pengumpulan Data}

Dalam penelitian ini, peneliti mengumpulkan data primer dengan cara kuesioner. Kuesioner merupakan pengumpulan data yang dilakukan dengan cara memberi seperangkat pernyataan tertulis kepada responden untuk dijawabnya (Sugiyono, 2012:199). Kuesioner diberikan kepada Kepala Bagian Akuntansi dan Staff Keuangan Perusahaan-Perusahaan Swasta di Provinsi Jawa Tengah yang dijadikan sampel penelitian atau responden penelitian.

Kuesioner atau daftar pertanyaan disusun dengan memperhatikan atau menerapkan Skala Likert, yaitu skala yang digunakan untuk mengukur sikap, pendapat, dan persepsi seseorang atau sekelompok orang tentang variabel penelitian. Dengan Skala Likert, maka variabel yang akan diukur dijabarkan menjadi indikator variabel. Kemudian indikator tersebut dijadikan sebagai titik tolak untuk menyusun item-item instrumen yang dapat berupa pernyataan atau pertanyaan (Sugiyono, 2012:200).

\subsection{Teknik Analisis Data}

\subsubsection{Uji Asumsi Klasik}

Karena analisa data yang digunakan dalam penelitian ini adalah analisa model regresi, maka untuk menentukan ketepatan model perlu dilakukan pengujian atas 
beberapa asumsi klasik yang mendasari model regresi. Penyimpangan asumsi klasik yang digunakan dalam penelitian ini meliputi uji multikolinearitas, uji autokorelasi, dan uji heterokedastisitas yang secara rinci dapat dijelaskan sebagai berikut:

1. Uji Normalitas

Uji normalitas adalah untuk menguji apakah model regresi, variabel independen, dan variabel dependennya memiliki distribusi data normal atau tidak. Model regresi yang baik adalah memiliki distribusi data normal atau mendekati normal. Uji normalitas dilakukan dengan uji kolmogorovsmirnov satu arah atau analisis grafis. Dasar pengambilan keputusan normal atau tidaknya data yang diolah adalah sebagai berikut (Ghozali, 2008:59):

a. Jika nilai $\mathrm{Z}$ hitung $>\mathrm{Z}$ tabel, maka distribusi sampel normal.

b. Jika nilai $\mathrm{Z}$ hitung $<\mathrm{Z}$ tabel, maka distribusi sampel tidak normal.

2. Uji Multikolinearitas

Multikolinearitas adalah suatu keadaan dimana satu atau lebih variabel independen dapat dinyatakan sebagai kombinasi linear dari variabel independen lainnya.

Multikolonearitas menyebabkan koefisien masing-masing variabel bebas secara statis menjadi tidak signifikan sehingga variabel bebas yang mempengaruhi variabel terikat tidak diketahui (Ghozali, 2008:62). Pendeteksian ada atau tidaknya multikolonearitas dalam penelitian ini dengan melihat nilai tolerance dan nilai Variance Inflation Factor (VIF). Ketentuannya adalah apabila nilai tolerance variabel independen kurang dari 0,10 dan nilai VIF lebih dari 10 , dapat dikatakan terjadi multikolonearitas. Sebaliknya apabila nilai tolerance variabel independen lebih dari 0,10 dan nilai VIF kurang dari 10, dikatakan tidak terjadi multikolonearitas. Jika terjadi multikolonearitas berarti tidak lolos uji.
3. Uji Autokorelasi

Pengujian autokorelasi digunakan untuk mengetahui apakah terjadi korelasi antara kesalahan pengganggu pada periode $t$ dengan kesalahan pada periode t-1 (sebelumnya). Model regresi yang baik adalah regresi yang bebas dari autokorelasi (Ghozali, 2008:61). Untuk mendeteksi terjadinya autokorelasi dapat dilakukan dengan pengujian terhadap nilai uji Durbin-Watson (Uji DW) dengan ketentuan sebagai berikut:

\section{Tabel 1}

Keterangan Nilai Uji Durbin-Watson

(Uji DW)

\begin{tabular}{ll}
\hline DW & Kesimpulan \\
\hline $\begin{array}{l}\text { Kurang dari } \\
\text { 1,08 }\end{array}$ & Ada autokorelasi \\
1,08 s/d 1,66 & Tanpa kesimpulan \\
1,66 s/d 2,34 & Tidak ada \\
& autokorelasi \\
2,34 s/d 2,92 & Tanpa kesimpulan \\
Lebih dari & Ada korelasi \\
2,92 & \\
\hline
\end{tabular}

4. Heterokedastisitas

Uji heteroskedastisitas adalah situasi tidak konstannya varians. Kasus ini terjadi apabila variabel gangguan tidak mempunyai varians yang sama untuk semua observasi. Akibat dari adanya heteroskedastisitas, penaksir OLS tetap tidak bisa tetapi tidak efisien (Catur Sugiyanto, 2004:54). Salah satu cara mendeteksi heteroskedastisitas adalah dengan menggunakan uji glesjer. Uji Glesjer dilakukan dengan cara meregresi logaritma residual kuadrat terhadap semua variabel penjelas.

\subsubsection{Analisis Regresi Berganda}

Analisis data yang digunakan dalam penelitian adalah metode analisis regresi dengan variabel moderator. Variabel moderating adalah variabel independen yang akan memperkuat atau memperlemah hubungan antara variabel independen lainnya terhadap variabel dependen.

Variabel pengendalian internal merupakan variabel moderator oleh karena dapat melemahkan atau memperkuat 
pengaruh ketaatan aturan akuntansi dan perilaku tidak etis terhadap kecenderungan kecurangan akuntansi, yang persamaannya dapat dikemukakan sebagai berikut:

$$
\begin{aligned}
& Y=a+b_{1} X_{1}+b_{2} X_{2}+b_{3} X_{3}+e, \\
& \text { dan } \\
& Y=a+b_{1} X_{1}+b_{2} X_{2}+b_{3} X_{3}+b_{4} \\
& X_{1} X_{3}+b_{5} X_{2} X_{3}+e \\
& \text { Keterangan: } \\
& Y \quad=\text { Kecenderungan Kecurangan } \\
& \quad \text { Akuntansi } \\
& X_{1} \quad=\text { Ketaatan Aturan Akuntansi } \\
& X_{2}=\text { Perilaku Tidak Etis } \\
& X_{3}=\text { Pengendalian Internal } \\
& a_{2} \alpha=\text { Konstantan Regresi } \\
& \beta, b_{1}, b_{2}, b_{3,} b_{4,} b_{5}=\text { Koefisien } \\
& \text { Regresi } \\
& \quad=\quad \text { Statistical Error }
\end{aligned}
$$

\section{HASIL PENELITIAN DAN PEMBAHASAN}

\subsection{Hasil Uji Asumsi Klasik}

Maksud dilakukakan pengujian asumsi dalam penelitian ini adalah untuk mendapatkan model regresi yang baik dan benar-benar mampu memberikan estimasi yang handal dan tidak bias. Analisis regresi juga menunjukkan arah hubungan antara variabel dependen dengan variabel independen. Teknik estimasi variable dependen yang melandasi independen analisis tersebut disebut Ordinary Least Squares (OLS).

Model regresi yang menggunakan teknik OLS, sering disebut sebagai model regresi linear klasik. Untuk dapat dianalisis hasilnya, model tersebut harus menggunakan asumsi OLS. Terdapat 10 asumsi OLS yang harus dipenuhi, tetapi pada umumnya hanya 4 uji yang harus dilakukan yaitu Uji Normalitas, Uji Heteroskedastisitas, Uji Autokorelasi, dan Uji Multikolinieritas. Pengujian ini dilakukan untuk meyakini bahwa model regresi yang diperoleh mempunyai kemampuan untuk memprediksi, dan kemanfaatan dalam pengambilan keputusan.

\subsubsection{Uji Multikolinieritas}

Multikolinieritas adalah suatu keadaan di mana salah satu atau lebih variabel independen dapat dinyatakan sebagai kombinasi linier dari variabel independen lainnya. Cara yang digunakan untuk mendeteksi ada tidaknya Multikolinieritas adalah dengan melakukan regresi antar variabel penjelas. Jika signifikan berarti terdapat Multikolinieritas. Untuk menguji Multikolinieritas dengan vasilitas yang disediakan SPSS yaitu dengan melihat nilai VIF dari masingmasing variabel. Jika nilai VIF lebih rendah dari 10, maka dapat disimpulkan bahwa tidak ada Multikolinieritas yang serius antara variabel independen dalam model. Dengan melihat nilai VIF dalam model regresi dapat diketahui bahwa masingmasing variabel tidak mengandung adanya gejala Multikolinieritas karena mempunyai nilai VIF yang lebih rendah dari 10 . Hal ini menunjukkan model regresi tersebut lolos uji Multikolinieritas.

Tabel 2

Ringkasan Hasil Pengujian

Multikolinieritas Dengan Menggunakan Varian Inflas Factor (VIF)

\begin{tabular}{|c|l|r|r|}
\hline \multirow{2}{*}{\multicolumn{2}{|c|}{ Model }} & \multicolumn{2}{c|}{$\begin{array}{c}\text { Collinearity } \\
\text { Statistics }\end{array}$} \\
\cline { 3 - 4 } & Tolerance & \multicolumn{1}{c|}{ VIF } \\
\hline 1 & (Constant) & & \\
\hline & $\begin{array}{l}\text { Ketaan.Aturan. } \\
\text { Akuntansi }\end{array}$ & .972 & 1.029 \\
\hline & $\begin{array}{l}\text { Perilaku.Tidak. } \\
\text { Etis }\end{array}$ & .986 & 1.014 \\
\hline & $\begin{array}{l}\text { Pengendalian.In } \\
\text { ternal }\end{array}$ & .977 & 1.024 \\
\hline
\end{tabular}

a Dependent Variable:

Kecenderungan.Kecurangan.Akuntansi

Tabel 2 memperlihatkan bahwa hasil perhitungan nilai tolerance menunjukkan tidak ada variabel independen yang memiliki nilai tolerance kurang dari 0,10 yang berarti tidak ada korelasi antar variabel independen yang nilainya lebih dari $95 \%$. Hasil perhitungan Variance Inflation Factor (VIF) juga menunjukkan 
hal yang sama, tidak ada satu variabel independen yang memiliki nilai VIF lebih dari 10. Jadi dapat disimpulkan bahwa tidak ada Multikolonieritas antar variabel independen dalam model regresi.

\subsubsection{Uji Autokorelasi}

Uji autokerelasi yang digunakan dalam penelitian ini adalah Uji DurbinWatson (DW Test). Uji Durbin Watson hanya digunakan untuk autokorelasi tingkat satu (first order autocorrelation) dan mensyaratkan adanya intercept (konstanta) dalam model regresi dan tidak ada variabel lagi di antara variabel indepeden. Selanjutnya uji autokerelasi Durbin-Watson (DW Test) dilakukan dengan menggunakan bantuan Program SPSS ver 21 for windows, hasil olah data terlihat seperti Tabel 3 . berikut:

\section{Tabel 3}

Hasil Uji Autokorelasi dengan DurbinWatson (DW Test)

\begin{tabular}{|l|c|r|r|r|r|}
\hline Model & R & R Square & $\begin{array}{c}\text { Adjusted } \\
\text { R Square }\end{array}$ & $\begin{array}{c}\text { Std. Enror } \\
\text { of the } \\
\text { Estimate }\end{array}$ & $\begin{array}{c}\text { Durbin- } \\
\text { Watson }\end{array}$ \\
\hline 1 & $.728(\mathrm{a})$ & 530 & 519 & .56442 & 2.227 \\
\hline
\end{tabular}

a Predictors: (Constant),

Pengendalian.Internal, Perilaku.Tidak.Etis, Ketaan.Aturan.Akuntansi

b Dependent Variable:

Kecenderungan.Kecurangan.Akuntansi

Tabel 4 memperlihatkan bahwa nilai DW sebesar 2.227. Nilai ini akan dibandingkan dengan nilai tabel dengan menggunakan nilai signifikansi 5\%, dengan jumlah sampel sebanyak 63 (n) dan jumlah variabel independen $3 \quad(k=3)$ sebagai berikut:

\section{Tabel 4}

Tabel Pengambilan Keputusan Uji Autokorelasi

\begin{tabular}{|l|c|c|}
\hline \multicolumn{1}{|c|}{ Kesimpulan } & Keputusan & Tika \\
\hline Ada autokorelasi & Tolak & Kurang dari 1,08 \\
Tanpa kesimpulan & No desicision & 1,08 s d 1,66 \\
Tidak ada autokorelasi & Tdk Tolak & 1,66 s d 2,34 \\
Tanpa kesimpulan & No desicision & 2,34 s d 2,92 \\
Ada korelasi & Ditolak & Lebih dari 2,92 \\
\hline
\end{tabular}

Sumber: Ghozali (2006:96)

Nilai DW 2.227 lebih besar dari batas atas (du) 1.66 dan kurang dari 2,34 (4-du), maka dapat disimpulkan bahwa tidak ada autokorelasi positif atau negatif. Dengan demikian dapat disimpulkan tidak terdapat autokorelasi.

\subsubsection{Uji Heterokedastisitas}

Uji heterokedastisitas bertujuan menguji apakah dalam model regresi terjadi ketidaksamaan variance dari residual suatu pengamatan ke pengamatan yang lain yang lain. Jika variance dari residual satu pengamatan ke pengamatan yang lain tetap, maka disebut homokedastisitas dan jika berbeda disebut heterokedastisitas. Selanjutnya uji heterokedastisitas dengan menggunakan Glejser dilakukan dengan menggunakan bantuan Program SPSS ver 21 for windows, hasil olah data terlihat seperti tabel 5 berikut:

Tabel 5

Hasil Uji Heterokedastisitas dengan Glejser

\begin{tabular}{|c|c|c|c|c|c|c|}
\hline \multirow[b]{2}{*}{$\begin{array}{l}\text { Mode } \\
1\end{array}$} & & \multicolumn{2}{|c|}{$\begin{array}{l}\text { Unstandardized } \\
\text { Coefficients }\end{array}$} & \multirow{2}{*}{$\begin{array}{c}\text { Standardized } \\
\text { Coefficients } \\
\text { Beta }\end{array}$} & \multirow[b]{2}{*}{$\mathrm{t}$} & \multirow[b]{2}{*}{ Sig. } \\
\hline & & $\mathrm{B}$ & $\begin{array}{l}\text { Std. } \\
\text { Error }\end{array}$ & & & \\
\hline \multirow[t]{4}{*}{1} & (Constant) & .079 & 1.162 & & .068 & .946 \\
\hline & $\begin{array}{l}\text { Ketaan.Aturan.Akunt } \\
\text { ansi }\end{array}$ & .044 & .119 & .048 & .369 & .713 \\
\hline & Perilaku.Tidak.Etis & .071 & .092 & .101 & .776 & .441 \\
\hline & Pengendalian.Internal & -.128 & .111 & -.150 & -1.153 & .254 \\
\hline
\end{tabular}

a Dependent Variable: Res_2 
Tabel 5 menunjukkan bahwa tidak ada satupun variabel independen yang signifikan secara statistik mempengaruhi variabel dependen nilai absolut $\mathrm{Y}$ atau $\mid \mathrm{Y}$ |. Hal ini terlihat dari probabilitas signifikansinya di atas 0,05 atau di atas tingkat kepercayaan 5\%, jadi dapat disimpulkan model regresi tidak mengandung adanya heterokedastisitas.
Uji normalitas bertujuan untuk menguji apakah dalam model regresi, variabel, pengganggu atau residual memiliki distribusi normal. Untuk menguji normalitas dalam penelitian ini peneliti menggunakan uji statistik dengan parametrik Kolmogrorov-Smirnow test (KS) dengan menggunakan bantuan Program SPSS ver 21 for windows, hasil olah data terlihat seperti Tabel 6 . berikut:

\subsubsection{Uji Normalitas}

Tabel 6

Hasil Normalitas dengan Kolmogrorov-Smirnow Test (K-S)

\begin{tabular}{|l|l|r|}
\hline \multicolumn{2}{|l|}{} & $\begin{array}{r}\text { Unstandardi } \\
\text { zed Residual }\end{array}$ \\
\hline $\mathrm{N}$ & Mean & 63 \\
\hline \multirow{2}{*}{$\begin{array}{l}\text { Normal } \\
\text { Parameters(a,b) }\end{array}$} & Std. Deviation & .0000000 \\
\hline \multirow{2}{*}{$\begin{array}{l}\text { Most Extreme } \\
\text { Differences }\end{array}$} & Absolute & .55059385 \\
\cline { 2 - 3 } & Positive & .096 \\
\cline { 2 - 3 } & Negative & .096 \\
\hline \multicolumn{2}{|l|}{ Kolmogorov-Smirnov Z } & .067 \\
\hline \multicolumn{2}{|l|}{ Asymp. Sig. (2-tailed) } & .764 \\
\hline
\end{tabular}

a Test distribution is Normal.

b Calculated from data.

Besarnya nilai KolmogorovSmimov adalah 0.604 dan menunjukkan keadaan yang tidak signifikan dengan nilai derajat probabilitas signifikansi atau $p$ value $>0,05$ atau $5 \%$. Hal ini berarti Ho diterima, yang artinya bahwa data residual berdistribusi normal atau dapat dikatakan telah lolos uji normalitas.

\subsection{Hasil Analisis Regressi}

Hasil analisis regresi linier berganda dengan program SPSS ver 21 for windows dimaksudkan untuk menganalisis tentang besarnya pengaruh dari variabel ketaatan aturan akuntansi, perilaku tidak etis dan pengendalian internal terhadap kecenderungan kecurangan akuntansi yaitu dengan melihat besar koefisien determinasi ( $\mathrm{R}$ Square). Dalam penelitian ini terdapat satu variabel dependent, yaitu kecenderungan kecurangan akuntansi, dan tiga variabel independent yaitu ketaatan aturan akuntansi, perilaku tidak etis dan pengendalian internal. Berdasarkan hal tersebut maka metode analisis yang digunakan adalah regresi berganda. Dari analisa regresi yang dilakukan dengan menggunakan bantuan Program SPSS ver 21 for windows, hasil olah data dapat diuraikan sebagai berikut:

\subsubsection{Pengaruh Ketaatan Aturan Akuntansi dan Perilaku Tidak Etis terhadap Kecenderungan Kecurangan Akuntansi \\ Hasil analisis pengaruh ketaatan aturan akuntansi dan perilaku tidak etis terhadap kecenderungan kecurangan akuntansi dapat dilihat pada tabel berikut:}


Tabel 7

Analisa Regresi Pengaruh Ketaatan Aturan Akuntansi dan Perilaku Tidak Etis terhadap Kecenderungan Kecurangan Akuntansi

\begin{tabular}{|c|c|c|c|c|c|c|}
\hline \multirow[b]{2}{*}{$\begin{array}{l}\text { Mode } \\
1\end{array}$} & & \multicolumn{2}{|c|}{$\begin{array}{l}\text { Unstandardized } \\
\text { Coefficients }\end{array}$} & \multirow{2}{*}{$\begin{array}{c}\text { Standardized } \\
\text { Coefficients } \\
\text { Beta }\end{array}$} & \multirow[t]{2}{*}{$\mathrm{t}$} & \multirow[t]{2}{*}{ Sig. } \\
\hline & & B & $\begin{array}{l}\text { Std. } \\
\text { Error }\end{array}$ & & & \\
\hline \multirow[t]{3}{*}{1} & (Constant) & 3.372 & .881 & & 3.828 & .000 \\
\hline & $\begin{array}{l}\text { Ketaan.Aturan.Akunt } \\
\text { ansi }\end{array}$ & .152 & .118 & .155 & 2.286 & .013 \\
\hline & Perilaku.Tidak.Etis & .261 & .091 & .344 & 2.852 & .006 \\
\hline
\end{tabular}

a Dependent Variable: Kecenderungan.Kecurangan.Akuntansi

Berdasarkan tabel di atas, maka persamaan regresi yang di dapat adalah sebagai berikut:

$$
\begin{aligned}
& \mathrm{Y}=3,372+0,152 \mathrm{X}_{1}+0,261 \mathrm{X}_{2} \\
& \text { Keterangan: } \\
& \mathrm{Y}=\text { Kecenderungan } \\
& \text { kecurangan akuntansi } \\
& \mathrm{X}_{1}=\text { Ketaatan aturan } \\
& \text { akuntansi } \\
& \mathrm{X}_{2} \quad=\text { Perilaku tidak etis } \\
& \text { Berdasarkan model regresi tersebut }
\end{aligned}
$$
diperoleh konstanta sebesar 3,372. Hal ini berarti bahwa tanpa ketaatan aturan akuntansi dan perilaku tidak etis maka akan terjadi perubahan kecenderungan kecurangan akuntansi sebesar 3,372. Selanjutnya koefisien regresi ketaatan aturan akuntansi sebesar 0,152 dan bertanda positif, hal ini berarti bahwa setiap perubahan ketaatan aturan akuntansi satu persen dengan asumsi variabel lainnya tetap maka perubahan kecenderungan kecurangan akuntansi akan mengalami perubahan sebesar 15,2\% dengan arah yang sama. Koefisien regresi perilaku tidak etis sebesar 0,261 dan bertanda positif, hal ini berarti bahwa setiap perubahan perilaku tidak etis satu persen dengan asumsi variabel lainnya tetap maka perubahan kecenderungan kecurangan akuntansi akan mengalami perubahan sebesar $26,1 \%$ dengan arah yang sama.

Persamaan model matematis di atas menunjukkan bahwa pengaruh perilaku tidak etis lebih dominan daripada ketaatan aturan akuntansi terhadap kecenderungan kecurangan akuntansi. Hal itu ditunjukkan dari koefisien regresi perilaku tidak etis yaitu 0,261 lebih besar dari koefisien regresi ketaatan aturan akuntansi yang bernilai 0,152 .

\subsubsection{Pengaruh Ketaatan Aturan Akuntansi dan Perilaku Tidak Etis terhadap Kecenderungan Kecurangan Akuntansi yang Dimoderasi Oleh Pengendalian Internal}

Hasil analisis pengaruh ketaatan aturan akuntansi dan perilaku tidak etis terhadap kecenderungan kecurangan akuntansi yang dimoderasi oleh pengendalian internal dapat dilihat pada tabel berikut: 


\section{Tabel 8}

Analisa Regresi Pengaruh Ketaatan Aturan Akuntansi dan Perilaku Tidak Etis terhadap Kecenderungan Kecurangan Akuntansi yang Dimoderasi Oleh Pengendalian Internal

\begin{tabular}{|c|c|c|c|c|c|c|}
\hline & \multirow[t]{2}{*}{ Model } & \multicolumn{2}{|c|}{$\begin{array}{l}\text { Unstandardized } \\
\text { Coefficients }\end{array}$} & \multirow{2}{*}{$\begin{array}{c}\text { Standardized } \\
\text { Coefficients } \\
\text { Beta }\end{array}$} & \multirow[b]{2}{*}{$\mathrm{t}$} & \multirow[b]{2}{*}{ Sig. } \\
\hline & & B & $\begin{array}{l}\text { Std. } \\
\text { Error }\end{array}$ & & & \\
\hline \multirow[t]{4}{*}{1} & (Constant) & 2.871 & 1.174 & & 2.445 & .017 \\
\hline & $\begin{array}{l}\text { Ketaan.Aturan.Akunt } \\
\text { ansi }\end{array}$ & .163 & .120 & .166 & 2.358 & .008 \\
\hline & Perilaku.Tidak.Etis & .265 & .092 & .350 & 2.879 & .006 \\
\hline & Pengendalian.Internal & .373 & .113 & .079 & 3.649 & .001 \\
\hline
\end{tabular}

a Dependent Variable: Kecenderungan.Kecurangan.Akuntansi

Berdasarkan hasil analisis pada tabel 8 di atas, maka dapat gambarkan kerangka struktur model sebagai berikut:

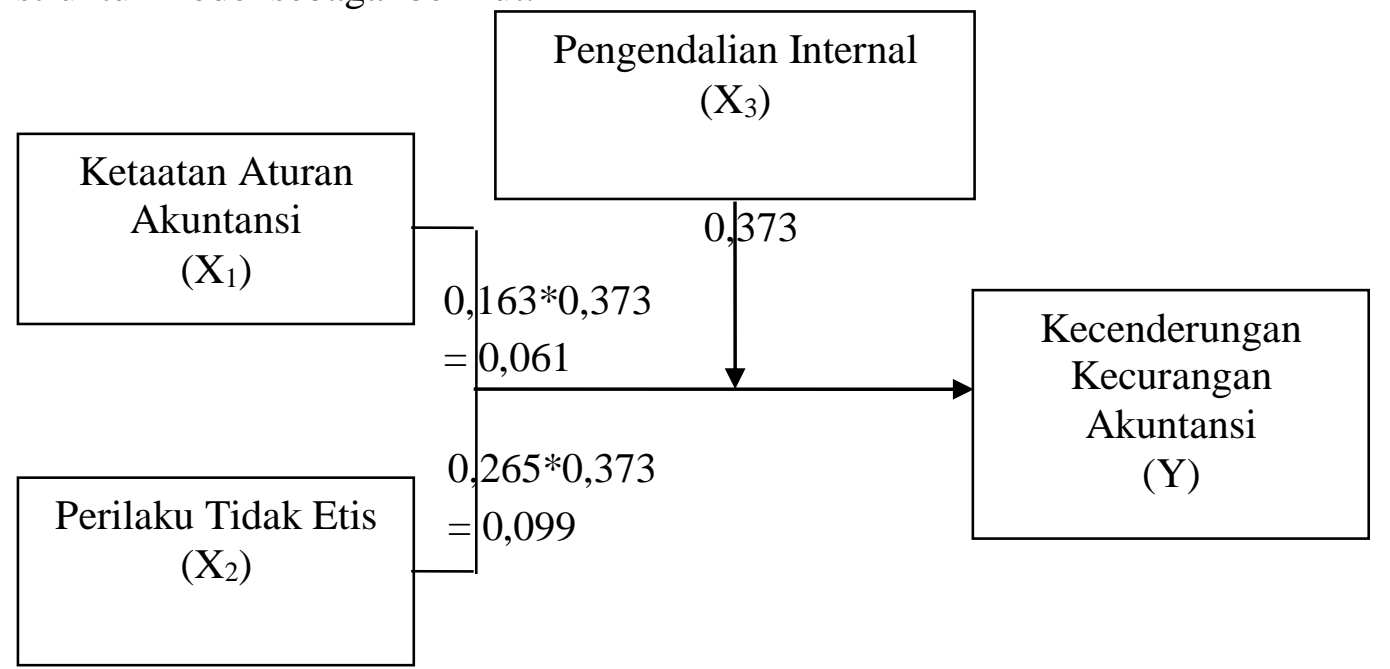

\section{Gambar 1 Model Struktural Moderating}

Berdasarkan gambar 1 di atas, maka persamaan regresi yang di dapat adalah sebagai berikut:

$$
\begin{aligned}
& \mathrm{Y}=2,871+0,163 \mathrm{X}_{1}+0,265 \mathrm{X}_{2} \\
& +0,373 \mathrm{X}_{3}+0,061 \mathrm{X}_{1} \mathrm{X}_{3}+0,099 \mathrm{X}_{2} \mathrm{X}_{3} \\
& \text { Keterangan: } \\
& \mathrm{Y}=\text { Kecenderungan }
\end{aligned}
$$
kecurangan akuntansi

akuntansi

$$
\mathrm{X}_{1}=\text { Ketaatan aturan }
$$

$\mathrm{X}_{2}=$ Perilaku tidak etis

$\mathrm{X}_{3}=$ Pengendalian internal

Berdasarkan model regresi tersebut diperoleh konstanta sebesar 2,871. Hal ini berarti bahwa tanpa ketaatan aturan akuntansi dan perilaku tidak etis yang dimoderasi oleh pengendalian internal maka akan terjadi perubahan kecenderungan perilaku tidak etis sebesar 2,871. Selanjutnya koefisien regresi ketaatan aturan akuntansi yang dimoderasi oleh pengendalian internal sebesar $(0,163+0,061) 0,224$ dan bertanda positif, hal ini berarti bahwa setiap perubahan ketaatan aturan akuntansi yang domoderasi oleh pengendalian internal satu persen dengan asumsi variabel lainnya tetap maka perubahan kecenderungan kecurangan akuntansi akan mengalami perubahan sebesar 22,4\% dengan arah yang sama. Koefisien regresi perilaku tidak etis yang dimoderasi oleh pengendalian internal 
sebesar $(0,265+0,099) 0,364$ dan bertanda positif, hal ini berarti bahwa setiap perubahan perilaku tidak etis yang domoderasi oleh pengendalian internal satu persen dengan asumsi variabel lainnya tetap maka perubahan kecenderungan kecurangan akuntansi akan mengalami perubahan sebesar $36,4 \%$ dengan arah yang sama.

Persamaan model matematis di atas menunjukkan bahwa pengaruh perilaku tidak etis yang domoderasi oleh pengendalian internal lebih dominan daripada ketaatan aturan akuntansi yang domoderasi oleh pengendalian internal terhadap kecenderungan kecurangan akuntansi. Hal itu ditunjukkan dari koefisien regresi perilaku tidak etis yaitu 0,364 lebih besar dari koefisien regresi ketaatan aturan akuntansi yang bernilai 0,224 .

\subsection{Pengujian Hipotesis}

Pengujian hipotesis berdasarkan hasil analisis yang telah dilakukan, maka dapat diuraikan sebagai berikut:

\subsubsection{Pengaruh Ketaatan Aturan Akuntansi terhadap Kecenderungan Kecurangan Akuntansi}

Berdasarkan

tabel

7

memperlihatkan bahwa nilai probabilitas signifikansi atau $\mathrm{p}$ value-nya adalah 0.013 atau lebih kecil dari 0.05 atau 5\% dan koefisien regresi-nya adalah positif 0,152 , selain itu berdasarkan analisis diperoleh nilai t-hitung 2,286 lebih kecil dari t-tabel 1,917 artinya hipotesis 1 yang menyatakan bahwa "Semakin taat perusahaan dalam menerapkan aturan akuntansi akan menyebabkan kecurangan akuntansi semakin menurun" dapat dibuktikan. Berdasarkan hal tersebut dapat disimpulkan bahwa ketaatan aturan akuntansi berpengaruh positif dan signifikan terhadap kecenderungan kecurangan akuntansi. Hasil ini sependapat dengan hasil penelitian Roberts et al., (2002:23) yang berpendapat bahwa cara profesi diorganisir, melalui antara lain kode etik, dan ketaatan atas aturan akuntansi, akan memberikan pengaruh serta mengendalikan perilaku manajemen perusahaan. Dengan demikian semakin perusahaan taat pada aturan akuntansi, semakin rendah kecenderungan kecurangan akuntansi yang dilakukan manajemen perusahaan.

Meningkatkan ketaatan pada aturan akuntansi pada sebuah perusahaan atau instantsi dapat mencegah terjadinya kecenderungan kecurangan akuntansi, yang nantinya akan membantu perusahaan untuk menyediakan informasi laporan keuangan perusahaan secara objektif kepada pihak yang berkepentingan. Teori perkembangan moral Kohlberg (2009:45), menyatakan bahwa moralitas manajemen yang tinggi juga didukung dengan ketaatan aturan yang berlaku. Dalam teori ini, pada tahap konvensional, manajemen berorientasi pada pada peraturan yang berlaku, sehingga ketaatan aturan akuntansi dapat membentuk moralitas manajemen yang tinggi dan dapat menurunkan kecenderungan kecurangan akuntansi yang dilakukan oleh manejemen. Thoyibatum

(2009:250)

mengatakan ketaatan aturan akuntansi dipandang sebagai tingkat kesesuaian prosedur pengelolaan aset organisasi, pelaksanaan prosedur akuntansi, dan penyajian laporan keuangan beserta semua bukti pendukung- nya, dengan aturan yang ditentukan oleh BPK dan/atau SAP (PP RI Nomor 24/2005. Dinyatakan mentaati aturan akuntansi jika PTN telah menerapkan persyaratan pengungkapan, menyajikan informasi yang bermanfaat bagi kepentingan publik, objektif, memenuhi syarat kehati-hatian dan memenuhi konsep konsistensi penyajian (PSAK No. 1, IAI, 2004).

\subsubsection{Pengaruh Perilaku Tidak Etis terhadap Kecenderungan Kecurangan Akuntansi \\ Berdasarkan tabel 7} memperlihatkan bahwa nilai probabilitas signifikansi atau $\mathrm{p}$ value-nya adalah 0.006 
atau lebih kecil dari 0.05 atau 5\% dan koefisien regresi-nya adalah positif 0,261 , selain itu berdasarkan analisis diperoleh nilai t-hitung 2,852 lebih kecil dari t-tabel 1,917 artinya hipotesis 2 yang menyatakan bahwa "Semakin meningkat perilaku tidak etis dalam perusahaan akan menyebabkan kecurangan akuntansi semakin meningkat" dapat dibuktikan. Berdasarkan hal tersebut dapat disimpulkan bahwa perilaku tidak etis berpengaruh positif dan signifikan terhadap kecenderungan kecurangan akuntansi. Hasil ini sependapat dengan hasil penelitian Griffin dan Ebert (2007:58) yang menyatakan bahwa perilaku tidak etis adalah perilaku yang tidak sesuai dengan norma-norma sosial yang diterima secara umum, sehubungan dengan tindakan yang bermanfaat atau yang membahayakan. Dalam teori perkembangan moral, Kohlberg (2009:267) menyatakan bahwa moral berkembang melalui tiga tahap yaitu (1) pra-konvensional, (2) konvensional dan (3) post-konvensional. Tahap postkonvensional merupakan akhir dari tahapan perkembangan moral yang membentuk prinsip etika yang dimiliki manajemen.

Prinsip tersebut menunjukkan sikap dari manajemen dalam mengelola perusahaan. Prinsip tersebut mewakili sikap manajemen dalam mengelola suatu perusahaan atau instansi. Jika perilaku yang ditunjukkan manajemen cenderung tidak etis maka kecenderungan kecurangan akuntansi akan semakin tinggi.

\subsubsection{Pengaruh Efektivitas Pengendalian Internal terhadap Kecenderungan Kecurangan Akuntansi}

Berdasarkan tabel 7 memperlihatkan bahwa nilai probabilitas signifikansi atau p value-nya adalah 0.001 atau lebih kecil dari 0.05 atau 5\% dan koefisien regresi-nya adalah positif 0,373 , selain itu berdasarkan analisis diperoleh nilai t-hitung 3,649 lebih kecil dari t-tabel 1,917 artinya hipotesis 3 yang menyatakan bahwa "Semakin efektif pengendalian internal dalam perusahaan akan menyebabkan kecurangan akuntansi semakin menurun" dapat dibuktikan. Berdasarkan hal tersebut dapat disimpulkan bahwa pengendalian internal berpengaruh positif dan signifikan terhadap kecenderungan kecurangan akuntansi. Hasil ini sependapat dengan hasil penelitian Wilopo (2006) menyimpulkan bahwa pengendalian internal yang efektif mampu menurunkan kecenderungan kecurangan akuntansi. Duke II dan Kankpang (2012) menyatakan ketidakefektifan pengendalian internal mendorong terjadinya kecurangan. Berbeda dengan hasil kesimpulan Wilopo (2006) dan Duke II serta Kankpang (2012), Maharani (2011) mendapatkan bahwa efektivitas pengendalian internal berpengaruh signifikan terhadap etika bisnis, namun efektivitas pengendalian internal tidak berpengaruh terhadap kecenderungan kecurangan akuntansi. Hal ini diperkuat oleh Anggraini (2013) yang menyatakan bahwa pengendalian internal berpengaruh negatif terhadap kecenderungan kecurangan akuntansi.

Tindakan seorang pemimpin maupun orang yang diberikan wewenang dipengaruhi oleh atribut penyebab (Green and Mitchell, dalam Waworuntu, 2003). Oleh sebab itu, diperlukan sistem pengendalian untuk mengurangi penyebab terjadinya tindakan yang tidak etis dan kecurangan akuntansi. Sistem pengendalian internal diharapkan mampu mengurangi adanya tindakan menyimpang yang dilakukan oleh manajemen. Manajemen cenderung melakukan tindakan menyimpang untuk memaksimalkan keuntungan pribadi. Salah satu contoh tindakan menyimpang yaitu kecenderungan melakukan kecurangan akuntansi.

Kecenderungan kecurangan akuntansi dapat terjadi apabila ada peluang untuk melakukan hal tersebut. Peluang yang besar membuat kecenderungan kecurangan akuntansi lebih sering terjadi. 
Peluang tersebut dapat dikurangi dengan sistem pengendalian internal yang baik. Pengendalian internal yang baik dapat mengurangi atau bahkan menutup peluang untuk melakuakan kecenderungan kecurangan akuntansi.

\subsubsection{Pengaruh Efektivitas Pengendalian Internal terhadap Ketaatan Aturan Akuntansi dan Dampaknya Kecenderungan Akuntansi \\ Berdasarkan Kecurangan pada

1

memperlihatkan bahwa nilai koefisien variabel ketaatan aturan akuntansi yang diperkuat oleh pengendalian internal sebesar 0,224. Selain itu berdasarkan tabel 7 nilai probabilitas signifikansi atau $\mathrm{p}$ value-nya adalah 0.008 , dan 0,001 yang berarti lebih kecil dari 0.05 atau $5 \%$, selain itu berdasarkan analisis diperoleh nilai thitung 2,358 dan 3,649 lebih kecil dari ttabel 1,917 artinya hipotesis 4 yang menyatakan bahwa "Efektivitas pengendalian internal menyebabkan ketaatan akuntansi dalm perusahan semkain meningkat dan mendorong kecurangan akuntansi semakin menurun" dapat dibuktikan. Berdasarkan hal tersebut dapat disimpulkan bahwa adanya pengendalian internal secara positif dan sinifikan dapat memperkuat ketaatan aturan akuntansi dan pengaruhnya terhadap kecenderungan kecurangan akuntansi. Pengendalian internal memegang peranan penting untuk menyerahkan ketaatan pada aturan akuntansi (Jayanti dan Rasmini, 2013; Laughlin, 2009). Pengendalian internal yang efektif agar seluruh karyawan khususnya karyawan bagian akunting dapat bekerja dan bertindak sesuai dengan aturan atau standar akuntansi. Ketidaktaatan pada aturan akuntansi akan menimbulkan kecurangan akuntansi (Wilopo, 2006).

\subsubsection{Pengaruh Efektivitas Pengendalian Internal terhadap Perilaku Tidak Etis dan Dampaknya pada Kecenderungan Kecurangan Akuntansi}

Berdasarkan gambar 1 memperlihatkan bahwa nilai koefisien variabel perilaku tidak etis yang diperkuat oleh pengendalian internal sebesar 0,364. Selain itu berdasarkan tabel 7 nilai probabilitas signifikansi atau $\mathrm{p}$ value-nya adalah 0.006 , dan 0,001 yang berarti lebih kecil dari 0.05 atau $5 \%$, selain itu berdasarkan analisis diperoleh nilai thitung 2,879 dan 3,649 lebih kecil dari ttabel 1,917 artinya hipotesis 5 yang menyatakan bahwa "Efektivitas pengendalian internal menyebabkan perilaku tidak etis dalam perusahaan semakin menurun dan mendorong kecurangan akuntansi semakin menurun" dapat dibuktikan. Berdasarkan hal tersebut dapat disimpulkan bahwa adanya pengendalian internal secara positif dan sinifikan dapat memperkuat penurunan perilaku tidak etis dan pengaruhnya terhadap kecenderungan kecurangan akuntansi. Pengendalian internal yang efektif akan menutup peluang terjadinya perilaku tidak etis (Fauwzi, 2011). Dalam penelitiannya Wilopo (2006) menyimpulkan bahwa pengendalian internal yang efektif dapat menurunkan perilaku tidak etis yang berdampak pada penurunan kecenderungan kecurangan akuntansi. Kesimpulan ini didukung oleh Jayanti dan Rasmini (2011: 191) dan Oseni (2011) yang menyatakan pengendalian internal berpengaruh signifikan pada perilaku tidak etis. Berbeda dengan hasil kesimpulan Wilopo (2006), Maharani (2011) mendapatkan bahwa efektivitas pengendalian internal berpengaruh signifikan terhadap etika bisnis, namun efektivitas pengendalian internal tidak 
berpengaruh terhadap kecenderungan kecurangan akuntansi.

Namun, pengendalian internal yang efektif sekalipun tidak menjamin kelangsungan hidup perusahan karena pengendalian ini mempunyai kelemahan, yakni dapat dimanfaatkan oleh karyawan bersangkutan yang berkolusi untuk kepentingan pribadinya. Dengan demikian, pengendalian internal yang efektif saja tidak cukup untuk menghindari kecenderungan kecurangan akuntansi yang dilakukan oleh karyawan.
4.4 Koefisien Determinasi $\left(R^{2}\right)$

Untuk mengukur seberapa jauh kemampuan variabel bebas dalam menerangkan variabel yang terikat digunakan koefisien determinasi, dari harga $\mathrm{R}^{2}$. Kelemahan mendasar penggunaan koefisien determinasi adalah bias terhadap jumlah variabel independen yang dimasukkan ke dalam model. Oleh karena itu banyak peneliti menganjurkan untuk menggunakan nilai $\mathrm{R}^{2}$ pada saat mengevaluasi model regresi yang terbaik. Hasil olah data SPSS ditunjukkan pada tabel berikut ini:

Tabel 9

Koefisien Determinasi

\begin{tabular}{|l|c|r|r|r|}
\hline Model & R & R Square & $\begin{array}{c}\text { Adjusted } \\
\text { R Square }\end{array}$ & $\begin{array}{c}\text { Std. Error } \\
\text { of the } \\
\text { Estimate }\end{array}$ \\
\hline 1 & $.728(\mathrm{a})$ & .530 & .519 & .56442 \\
\hline
\end{tabular}

a Predictors: (Constant), Pengendalian.Internal, Perilaku.Tidak.Etis, Ketaan.Aturan.Akuntansi

b Dependent Variable: Kecenderungan.Kecurangan.Akuntansi

Berdasarkan tampilan output SPSS model summary atau tabel 9 tersebut di atas, besarnya $\mathrm{R}^{2}$ adalah 0,530 hal ini berarti $53 \%$ variabel dependen kecenderungan kecurangan akuntansi dapat dijelaskan atau dipengaruhi oleh variabel independen ketaatan aturan akuntansi, perilaku tidak etis dan pengendalian internal, sedangkan sisanya $47 \%$ (100\%-53\%) dijelaskan oleh sebabsebab yang lain di luar model.

\section{KESIMPULAN}

Berdasarkan rumusan masalah, tujuan penelitian dan hipotesis penelitian sera hasil penelitian dan pembahasan, maka dapat disimpulkan hal-hal sebagai berikut:

1. Ketaatan aturan akuntansi berpengaruh positif dan signifikan terhadap kecenderungan kecurangan akuntansi. Artinya semakin taat PerusahaanPerusahaan Swasta Di Provinsi Jawa Tengah dalam menerapkan aturan akuntansi akan menyebabkan kecurangan akuntansi semakin menurun. Meningkatkan ketaatan pada aturan akuntansi pada sebuah perusahaan atau instantsi dapat mencegah terjadinya kecenderungan kecurangan akuntansi, yang nantinya akan membantu perusahaan untuk menyediakan informasi laporan keuangan perusahaan secara objektif kepada pihak yang berkepentingan.

2. Perilaku tidak etis berpengaruh positif dan signifikan terhadap kecenderungan kecurangan akuntansi. Artinya semakin meningkat perilaku tidak etis dalam perusahaan akan menyebabkan kecurangan akuntansi semakin meningkat. Perilaku tidak etis adalah perilaku yang tidak sesuai dengan norma-norma sosial yang diterima secara umum, sehubungan dengan tindakan yang bermanfaat atau yang membahayakan. Jika perilaku yang ditunjukkan manajemen cenderung tidak etis maka kecenderungan kecurangan akuntansi akan semakin tinggi. 
3. Pengendalian internal berpengaruh positif dan signifikan terhadap kecenderungan kecurangan akuntansi. Artinya semakin efektif pengendalian internal dalam perusahaan akan menyebabkan kecurangan akuntansi semakin menurun. Kecenderungan kecurangan akuntansi dapat terjadi apabila ada peluang untuk melakukan hal tersebut. Peluang tersebut dapat dikurangi dengan sistem pengendalian internal yang baik. Pengendalian internal yang baik dapat mengurangi atau bahkan menutup peluang untuk melakuakan kecenderungan kecurangan akuntansi.

4. Pengendalian internal secara positif dan sinifikan dapat memperkuat ketaatan aturan akuntansi dan pengaruhnya terhadap kecenderungan kecurangan akuntansi. Artinya semakin efektif pengendalian internal menyebabkan ketaatan akuntansi dalm perusahan semkain meningkat dan mendorong kecurangan akuntansi semakin menurun.

5. Pengendalian internal secara positif dan sinifikan dapat memperkuat perilaku tidak etis dan pengaruhnya terhadap kecenderungan kecurangan akuntansi. Artinya semakin efektif pengendalian internal menyebabkan perilaku tidak etis dalam perusahaan semakin menurun dan mendorong kecurangan akuntansi semakin menurun.

\section{DAFTAR PUSTAKA}

Abdullatif, Modar. 2013. "Fraud Risk Factors and Audit Programme Modifications: Evidence from Jordan", Australasian Accounting Business and Finance Journal, Vol. 7 , Issue, 1, pp. 57-77.

Ali Irfan, 2002. "Pelaporan Keuangan dan Asimetri Informasi dalam Hubungan Agensi", Lintasan Ekonomi_, Vol. XIX. No.2. Juli 2002
BPK RI, 2009, Prosedur Manajemen Insiden Pada Manajemen Helpdesk da Dukungan TI, BPK RI, Jakarta

Catur Sugianto, 1994. Ekonometrika Terapan, Yogyakarta : BPFE

Cohen, Jeffrey, Ding, Yuan, Lesage, Cedric, dan Stolowy, Herve. 2010. "Corporate Fraud and Managers' Behavior: Evidence from the Press", Journal of Business Ethics, Vol. 95, pp. 271-315.Dito (2010:44

Dito, Herdian. 2010. Pengaruh Kompensasi Terhadap Prestasi Kerja Karyawan PT. Slamet Langgeng Purbalingga dengan Motivasi Kerja Sebagai Variabel Intervening. www.ejurnal.com (17 Januari 2013)

Ghozali, Imam. 2013. Aplikasi Analisis Multivariate dengan Program SPSS. 21 Update PLS Regresi. Semarang: Undip.

Hendriksen, Van Breda. 2002. Teori Akutansi, Penerbit Interaksa, Bata

I.E. Sutherland, 2010, The Ultimate Display, invited lecture, IFIP Congress 65. An abstract appears in Information Processing 1965: Proc. IFIP Congress 65, Vol. 2

IAI. 2008. Standar Profesional Akuntan Publik. Jakarta: Salemba Empat

Kelly, J. \& Gennard, J. 2007, The role of personnel directors on the board of directors. Personnel Review, 26 (1), Jakarta

Keraf, A. Sonny, 2008. Etika Bisnis, Yogyakarta: Kanisius, hlm.81

Kohlberg, L. 2009. Stage and Sequence: The Cognitive Development Approach to Socialization, in D. Goslin (Ed.), Handbook of Socialization Theory and Research, (pp. 347-480). Chicago: Rand McNally

Laughlin, Chad. 2009. "Rebuilding the Foundation Reestablishing Ethics in the Accounting Professsion". Senior Thesis in the Honors Program Liberty University, pp. 1-32.

Mathis dan Jackson. 2000. Manajemen Sumber Daya Manusia. PT Salemba Emban Patria. Jakarta 
Mulyadi dan Puradiredja, K. 2008. Auditing. Edisi ke-5. Salemba Empat, Jakarta

Piaget, Jean. 2008. Terjemahan Gabain, Marjorie 1965. The moral judgment of the Child. New York: The Free Press.

Prasetyo, B., 2011. Metode Penelitian Kuantitatif, Jakarta: Rajawali Press

Rawashdeh, Nahed Habis Hamed Al. 2013. "The Role of the Auditor in Verified of the Unethical Practices in Accounting", Vol. 3, No. 7. pp. 1-9.

Robinson, Michael A. 2005. Akuntansi di Indonesia, buku satu. Terjemahan Soekusumo. Salemba Empat, Jakarta.

Scott, William R., 2003, Financial Accounting Theory, Third Edition, University of Waterloo.

Solomon, M. R. 1984. Consumer Behavior: Buying, Having, and Being. New Jersey, Upper Saddle River: Pearson Educatio n, Inc.
Sugiyono, 2012, Metode Penelitian Kuantitatif, Kualitatif dan $R \& D$, Penerbit Alfabeta, Bandung

Tang, T. L. P. and Randy K. Chiu, 2003. Income, Money Etic, Pay Satisfaction, Commitment, and Unethical Behavior: Is the Love of Money the Root of Evil for Hong Kong Employees? Journal of Business Ethics.

Thoyibatun, Siti. 2008. Faktor-Faktor yang Berpengaruh Terhadap Perilaku Tidak Etis Dan Kecenderungan Kecurangan Akuntansi Serta Akibatnya Terhadap Kinerja Organisasi. Jurnal Ekonomi dan Keuangan.

Waworuntu, Bob. 2003. Manajemen Sumber Daya Manusia. Jakarta : PT. Toko Gunung Agung.

Wilopo. 2006. Analisis Faktor-faktor yang Berpengaruh Terhadap Kecenderunga Kecurangan Akuntansi. Simposium Nasional Akuntansi 9. Padang. 